\title{
Yersinia ruckeri sp. nov., the Redmouth (RM) Bacterium
}

\author{
W. H. EWING, $†$ A. J. ROSS, $\dagger \dagger$ DON J. BRENNER, $\dagger+\dagger$ AND G. R. FANNING \\ Division of Biochemistry, Walter Reed Army Institute of Research, Washington, D.C. 20012
}

Cultures of the redmouth (RM) bacterium, one of the etiological agents of redmouth disease in rainbow trout (Salmo gairdneri) and certain other fishes, were characterized by means of their biochemical reactions, by deoxyribonucleic acid (DNA) hybridization, and by determination of guanine-plus-cytosine $(\mathrm{G}+\mathrm{C})$ ratios in DNA. The DNA relatedness studies confirmed the fact that the RM bacteria are members of the family Enterobacteriaceae and that they comprise a single species that is not closely related to any other species of Enterobacteriaceae. They are about 30\% related to species of both Serratia and Yersinia. A comparison of the biochemical reactions of RM bacteria and serratiae indicated that there are many differences between these organisms and that biochemically the RM bacteria are most closely related to yersiniae. The $G+C$ ratios of $R M$ bacteria were approximated to be between 47.5 and $48.5 \%$. These values are similar to those of yersiniae but markedly different from those of serratiae. On the basis of their biochemical reactions and their $\mathrm{G}+\mathrm{C}$ ratios, the $\mathrm{RM}$ bacteria are considered to be a new species of Yersinia, for which the name Yersinia ruckeri is proposed. Strain 2396-61 (= ATCC 29473) is designated the type strain of the species.

In 1966, Ross et al. (17) gave a description of a gram-negative, rod-shaped, oxidase-negative, peritrichous, fermentative bacterium that was isolated on numerous occasions from kidney tissues of rainbow trout (Salmo gairdneri) afflicted with redmouth disease. It was concluded that the redmouth (RM) bacteria were members of the family Enterobacteriaceae, but at that time it was not possible to determine with certainty their taxonomic position within the family. In addition, Ross et al. (17) reported the results of serological studies with cultures of the RM bacterium as well as transmission of the disease from infected to normal fish through the medium of water.

Redmouth disease syndrome in rainbow trout has been known for many years (18). The syndrome can be produced by certain aeromonads and pseudomonads, as well as by the bacterium reported on here $(17,18,20)$. The disease is systemic, and its major gross characteristic is inflammation in the areas of the mouth and throat. It is also known as pink mouth and pink or red throat. Clinical and pathological aspects of the disease have been reviewed by others (e.g., see references 18 and 20). The disease is enzootic in some private, state, and federal hatcheries and has become epizootic on occasion. As an epizootic in hatcheries, the disease

† Present address: P.O. Box 33276, Decatur, GA 30033.

†+ Present address: 2102 Rucker St., Everett, WA 98201.

$+\dagger \dagger$ Present address: Enteric Section, Center for Disease Control, Atlanta, GA 30333. constitutes an important economic problem. An outbreak of redmouth disease, in which the RM bacterium was incriminated, has been reported in Saskatchewan, Canada (20).

The purpose of this paper is to characterize the RM bacterium, to name and classify it properly, and to designate the type strain of the species.

\section{MATERIALS AND METHODS}

During the last 15 years, cultures of the RM bacterium (17) were isolated, by aseptic technique, from several hundred specimens of kidney tissue of rainbow and steelhead trout or sockeye and Chinook salmon. Most cultures were from rainbow trout. The 33 strains reported upon originated in fishes from hatcheries in Alaska, Arizona, California, Idaho, Ohio, Tennessee, and Washington (Table 1).

The methods used for determining the biochemical characteristics of the above-mentioned strains were the same as those described elsewhere $(11,12,17)$. Over a period of more than 10 years, the strains were tested several times on all substrates. Incubation was at 35 to $37^{\circ} \mathrm{C}$ and at 22 to $25^{\circ} \mathrm{C}$.

The techniques used in the isolation and purification of deoxyribonucleic acid (DNA), in DNA reassociation, and in the separation of single- and doublestranded DNA on hydroxyapatite have been described in detail $(5,8,9)$. The guanine-plus-cytosine $(G+C)$ percentages were approximated by carefully denaturing double-stranded DNA in a spectrophotometer at a wavelength of $260 \mathrm{~nm}$. Sealed cuvettes contained $100 \mu \mathrm{g}$ of DNA in $1 \mathrm{ml}$ of $0.15 \mathrm{M}$ sodium chloride- 0.015 $M$ sodium citrate. The temperature was raised $0.4^{\circ} \mathrm{C}$ per min from 40 to $95^{\circ} \mathrm{C}$ by means of a circulating 
TABLE 1. Strains of Yersinia ruckeri sp. nov. studied

\begin{tabular}{|c|c|c|c|}
\hline $\begin{array}{c}\text { Center } \\
\text { for } \\
\text { Disease } \\
\text { Control } \\
\text { Strain } \\
\text { no. }\end{array}$ & $\begin{array}{c}\text { BWF }^{a} \\
\text { strain } \\
\text { no. }\end{array}$ & Source & $\begin{array}{c}\text { Geographic } \\
\text { origin }\end{array}$ \\
\hline $2396-61$ & $\mathbf{H 1}$ & Rainbow trout & Idaho \\
\hline $2397-61$ & H31 & Rainbow trout & Idaho \\
\hline $2398-61$ & $\mathrm{H} 2$ & Rainbow trout & Idaho \\
\hline $2399-61$ & Н30 & Rainbow trout & Idaho \\
\hline $5972-61$ & H3 & Rainbow trout & Idaho \\
\hline $2973-61$ & $\mathrm{H} 12$ & Rainbow trout & Idaho \\
\hline $5974-61$ & H18 & Rainbow trout & Idaho \\
\hline $5975-61$ & $\mathrm{H} 28$ & Rainbow trout & Idaho \\
\hline $5976-61$ & $\mathrm{H} 29$ & Rainbow trout & Idaho \\
\hline $5977-61$ & H35 & Rainbow trout & Idaho \\
\hline $2514-63$ & H53 & Rainbow trout & Washington \\
\hline $2515-63$ & H56 & Rainbow trout & Washington \\
\hline $2516-63$ & H57 & Rainbow trout & Washington \\
\hline $2517-63$ & H60 & Rainbow trout & Washington \\
\hline $1558-68$ & H5 & Rainbow trout & Washington \\
\hline $1559-68$ & $\mathrm{H} 10$ & Rainbow trout & Washington \\
\hline $1560-68$ & $\mathrm{H} 23$ & Rainbow trout & Washington \\
\hline $1561-68$ & $\mathrm{H} 27$ & Rainbow trout & Washington \\
\hline $1562-68$ & H33 & Rainbow trout & Washington \\
\hline $1563-68$ & $\mathrm{H} 44$ & Rainbow trout & Washington \\
\hline $1564-68$ & $\mathrm{H} 48$ & Rainbow trout & Washington \\
\hline $4535-69$ & DBE1 & Trout & Washington \\
\hline $4536-69$ & $\mathrm{DBB1}$ & Trout & Washington \\
\hline $1846-73$ & $600-16$ & Rainbow trout & Washington \\
\hline $1847-73$ & $600-17$ & Rainbow trout & Washington \\
\hline $2848-73$ & $600-18$ & Chinook salmon & Washington \\
\hline $1849-73$ & $600-19$ & Sockeye salmon & Alaska \\
\hline $1850-73$ & $600-25$ & Rainbow trout & Idaho \\
\hline $1851-73$ & $600-25 A$ & Rainbow trout & Idaho \\
\hline $1852-73$ & $600-27$ & Chinook salmon & Washington \\
\hline $2674-73$ & $600-28$ & Steelhead trout & Washington \\
\hline $2675-73$ & $600-29$ & Fish & Tennessee \\
\hline $2676-73$ & $600-30$ & Rainbow trout & Ohio \\
\hline
\end{tabular}

${ }^{a}$ All strains were received from the Bureau of Wildlife and Fisheries (BWF), Seattle, Wash.

water bath that pumped water through heating coils within the cuvette holder.

\section{RESULTS}

The results of examination of the biochemical reactions given by cultures of the RM bacterium are given in detail in Table 2 and are summarized in Table 3. The data presented in the tables are largely self-explanatory and require little comment; they differ little from those reported earlier (17).

The $\mathrm{RM}$ bacterium grew better at 22 to $25^{\circ} \mathrm{C}$ than at 35 to $37^{\circ} \mathrm{C}$ (Table 2). In fact, growth may not occur on simple media when such media are incubated at the higher temperature. It may be noted that the biochemical reactions of the 33 strains were quite uniform despite the fact that the strains originated in several geographi- cal locations. Detectable gas was formed infrequently from fermentable substrates (Tables 2 and 3). Most isolates yielded negative VogesProskauer tests, but $24 \%$ gave weakly positive reactions, most of which were delayed (4 days) when the cultures were incubated at 22 to $25^{\circ} \mathrm{C}$ (Tables 2 and 3 ). Some strains fermented lactose slowly (14 days). However, all gave positive tests for beta-galactosidase activity within $1 \mathrm{~h}$ with cultures incubated at 22 to $25^{\circ} \mathrm{C}$, whereas strains incubated at 35 to $37^{\circ} \mathrm{C}$ were negative at $1 \mathrm{~h}$ but became positive upon continued incubation (18 to $24 \mathrm{~h}$ ). A majority of isolates were lipolytic (at 22 to $25^{\circ} \mathrm{C}$ ), but none was pectolytic or oxidase positive. All of the strains utilized glucose fermentatively (Hugh and Leifson medium), and all except two reduced nitrate to nitrite.

DNA from RM strain 4535-69 was labeled with ${ }^{32} \mathrm{PO}_{4}$, sheared, denatured, and reacted with similarly prepared unlabeled DNA from other RM bacteria and representatives of Enterobacteriaceae (Table 4). DNAs from RM bacteria were $95 \%$ related, and the related sequences contained almost no unpaired bases $(0.1$ to $0.2 \%$ divergence [D]). The RM bacterium was $9 \%$ related to Proteus mirabilis and Edwardsiella tarda and 15 to $31 \%$ related to other species of Enterobacteriaceae. The related sequences showed 13 to $18 \% \mathrm{D}$. Of the species tested, Serratia marcescens, $\mathrm{S}$. liquefaciens, and " $\mathrm{Ci}$ trobacter-like" (19) microorganisms were the closest relatives of RM bacteria. DNA relatedness results reported elsewhere show that " $\mathrm{C} i$. trobacter-like" organisms are $50 \%$ related to species of Serratia and are, in all probability, members of the genus Serratia (19).

Subsequent experiments with labeled DNA from species of Serratia and Yersinia (Table 5) showed that RM bacteria were 24 to $30 \%$ related to species of Serratia (16.5 to $17 \%$ D) and $30 \%$ related to two species of Yersinia (15\% D). Only closely related sequences can reassociate at $75^{\circ} \mathrm{C}$. At this temperature, relatedness of RM bacteria to serratiae and yersiniae decreased by three- to fourfold.

$\mathrm{G}+\mathrm{C}$ determinations were done spectrophotometrically (Fig. 1). The G+C contents of the RM bacteria were approximately 47.5 to $48.5 \%$, quite close to the values established for species of Yersinia (16).

\section{DISCUSSION}

Ross et al. (i7) considered the RM bacteria to be members of the family Enterobacteriaceae but were unable to assign them to any of the genera or species then contained in that family. They pointed out that in some respects the 
TABLE 2. Biochemical characteristics of Yersinia ruckeri sp. nov.

\begin{tabular}{|c|c|c|c|c|c|c|c|c|}
\hline \multirow{3}{*}{ Test or substrate } & \multicolumn{8}{|c|}{ No. of strains giving result ${ }^{a}$ indicated } \\
\hline & \multicolumn{4}{|c|}{$\begin{array}{c}\text { Incubation at } 22 \text { to } 25^{\circ} \mathrm{C}(33 \\
\text { strains) }\end{array}$} & \multicolumn{4}{|c|}{$\begin{array}{c}\text { Incubation at } 35 \text { to } 37^{\circ} \mathrm{C}(23 \\
\text { strains) }\end{array}$} \\
\hline & $\stackrel{+}{1-2^{b}}$ & $\begin{array}{l}(+) \\
3-7 \\
\end{array}$ & $\begin{array}{c}(+) \\
8-14 \\
\end{array}$ & - & $\stackrel{+}{1-2^{b}}$ & $\begin{array}{l}(+) \\
3-7 \\
\end{array}$ & $\begin{array}{c}(+) \\
8-14\end{array}$ & - \\
\hline Hydrogen sulfide ${ }^{c}$ & 0 & & & 33 & 0 & & & 23 \\
\hline Urease $\ldots \ldots \ldots \ldots \ldots \ldots \ldots \ldots \ldots \ldots \ldots$ & 0 & & & 33 & 0 & & & 23 \\
\hline$\ldots \ldots \ldots \ldots \ldots$ & 0 & & & 33 & 0 & & & 23 \\
\hline$\ldots \ldots \ldots \ldots \ldots \ldots$ & 32 & & & 1 & 22 & & & 1 \\
\hline$\ldots \ldots \ldots \ldots \ldots$ & 1 & 9 & & 23 & 0 & & & 23 \\
\hline$\ldots \ldots \ldots \ldots \ldots$ & 1 & 31 & & 1 & 0 & & & 23 \\
\hline$\ldots \ldots \ldots \ldots \ldots$ & 8 & & & 25 & 4 & & & 19 \\
\hline$\ldots \ldots \ldots \ldots \ldots \ldots$ & 27 & & & 6 & 0 & 6 & & 17 \\
\hline Gelatin liquefaction $\ldots \ldots \ldots \ldots \ldots$ & 17 & 14 & & 2 & NT & NT & & \\
\hline Lysine decarboxylase $\ldots \ldots \ldots \ldots \ldots \ldots$ & 29 & 4 & & $\mathbf{0}$ & 1 & 20 & & 2 \\
\hline Arginine dihydrolase $\ldots \ldots \ldots \ldots \ldots$ & 1 & & & 32 & 1 & 4 & & 18 \\
\hline Ornithine decarboxylase $\ldots \ldots \ldots \ldots$ & 33 & & & 0 & 23 & & & 0 \\
\hline Phenylalanine deaminase $\ldots \ldots \ldots \ldots$ & 0 & & & 33 & 0 & & & 23 \\
\hline \multicolumn{9}{|l|}{ Glucose } \\
\hline$\ldots \ldots \ldots \ldots \ldots \ldots \ldots$ & 33 & & & 0 & 23 & & & 0 \\
\hline$\ldots \ldots \ldots \ldots \ldots \ldots \ldots$ & $3^{d}$ & & & 30 & 1 & & & 22 \\
\hline$\ldots \ldots \ldots \ldots \ldots \ldots \ldots$ & 0 & & $4^{e}$ & 29 & 0 & & & 23 \\
\hline$\ldots \ldots \ldots \ldots \ldots \ldots$ & 0 & & & 33 & 0 & & & 23 \\
\hline$\ldots \ldots \ldots \ldots \ldots$ & 33 & & & 0 & 23 & & & 0 \\
\hline$\ldots \ldots \ldots \ldots \ldots \ldots \ldots \ldots$ & 0 & & & 33 & 0 & & & 23 \\
\hline$\ldots \ldots \ldots \ldots \ldots \ldots \ldots \ldots$ & 0 & & & 33 & 0 & & & 23 \\
\hline$\ldots \ldots \ldots \ldots \ldots \ldots \ldots \ldots$ & 0 & & & 33 & 0 & & & 23 \\
\hline$\ldots \ldots \ldots \ldots \ldots \ldots \ldots \ldots$ & 0 & & & 33 & 0 & & & 23 \\
\hline Sorbitol $\ldots \ldots \ldots \ldots \ldots \ldots \ldots \ldots \ldots \ldots \ldots \ldots$ & 0 & & & 33 & $1^{w}$ & & & 22 \\
\hline Arabinose $\ldots \ldots \ldots \ldots \ldots \ldots \ldots$ & 0 & & & 33 & $1^{w}$ & & & 22 \\
\hline Raffinose $\ldots \ldots \ldots \ldots \ldots \ldots \ldots \ldots$ & 0 & & & 33 & 2 & & & 21 \\
\hline Rhamnose $\ldots \ldots \ldots \ldots \ldots \ldots \ldots \ldots$ & 0 & & & 33 & 0 & & & 23 \\
\hline Malonate $\ldots \ldots \ldots \ldots \ldots \ldots \ldots \ldots$ & 0 & & & 33 & 0 & & & 23 \\
\hline$\ldots \ldots \ldots \ldots \ldots \ldots \ldots$ & 0 & & & 33 & $\mathbf{0}$ & & & 23 \\
\hline Christensen citrate & 25 & 8 & & 0 & 3 & 6 & & 14 \\
\hline$\ldots \ldots \ldots \ldots \ldots$ & 0 & 8 & & 25 & 0 & & & 23 \\
\hline Ammonium salts-glucose agar . . . . . . . & 1 & 13 & & 0 & NT & NT & & \\
\hline Sodium alginate $\ldots \ldots \ldots \ldots \ldots \ldots$ & 0 & & & 33 & 0 & & & 23 \\
\hline Lipase (corn oil) $\ldots \ldots \ldots \ldots \ldots \ldots \ldots$ & 18 & 7 & & 8 & 0 & & & 23 \\
\hline Maltose $\ldots \ldots \ldots \ldots \ldots \ldots \ldots \ldots \ldots \ldots$ & 33 & & & 0 & 22 & & & 1 \\
\hline Xylose $\ldots \ldots \ldots \ldots \ldots \ldots \ldots \ldots$ & 0 & & & 33 & 0 & & & 23 \\
\hline$\ldots \ldots \ldots \ldots \ldots \ldots$ & 32 & & & 1 & 21 & & & 2 \\
\hline$\ldots \ldots \ldots \ldots \ldots \ldots$ & $\mathbf{0}$ & & & 33 & $1^{w}$ & & & 22 \\
\hline$\ldots \ldots \ldots \ldots$ & 23 & 5 & & 5 & 0 & 5 & & 18 \\
\hline Alpha-methylglucoside $\ldots \ldots \ldots \ldots \ldots$ & 0 & & & 33 & 0 & & & 23 \\
\hline Erythritol $\ldots \ldots \ldots \ldots \ldots \ldots \ldots \ldots$ & 0 & & & 33 & 0 & & & 23 \\
\hline Esculin $\ldots \ldots \ldots \ldots \ldots \ldots \ldots \ldots \ldots$ & 0 & & & 33 & 0 & & & 23 \\
\hline Mannose $\ldots \ldots \ldots \ldots \ldots \ldots \ldots$ & 32 & 1 & & 0 & 23 & & & 0 \\
\hline Melibiose $\ldots \ldots \ldots \ldots \ldots \ldots$ & 0 & & & 33 & 0 & & & 23 \\
\hline$\ldots \ldots \ldots \ldots \ldots$ & 0 & & & 33 & 0 & & & 23 \\
\hline Beta-galactosidase $\ldots \ldots \ldots \ldots \ldots$ & 33 & & & 0 & 20 & & & 3 \\
\hline Deoxyribonuclease . . . . . . . . . . & 0 & & & 33 & 0 & & & 23 \\
\hline Nitrate to nitrite $\ldots \ldots \ldots \ldots \ldots \ldots \ldots$ & 28 & 4 & & 1 & 17 & & & 6 \\
\hline Oxidation-fermentation $\ldots \ldots \ldots \ldots \ldots$ & $33 F$ & & & & $23 \mathrm{~F}$ & & & \\
\hline Oxidase $\ldots \ldots \ldots \ldots$ & 0 & & & 33 & 0 & & & 23 \\
\hline$\ldots \ldots \ldots \ldots$ & 0 & & & 33 & $\mathbf{0}$ & & & 23 \\
\hline$\ldots \ldots \ldots \ldots \ldots$ & 0 & $8^{w}$ & & 25 & 0 & & & 23 \\
\hline$\ldots \ldots \ldots \ldots \ldots \ldots$ & 0 & & & 33 & 0 & & & 23 \\
\hline \multicolumn{9}{|l|}{ Organic acids $f$} \\
\hline Citrate .... & 0 & & 31 & 0 & 0 & & & 23 \\
\hline$\ldots \ldots \ldots \ldots \ldots \ldots$ & 0 & & & 33 & 0 & & & 23 \\
\hline
\end{tabular}

${ }^{a}$ Symbols: $w$, weakly positive reaction; $F$, fermentative; + , positive reaction within $48 \mathrm{~h} ;(+)$, positive reaction between 3 and 14 days; -, negative reaction after 14 days; NT, not tested.

${ }^{b}$ Days of incubation.

c Triple sugar-iron or peptone-iron agar.

$d$ Tiny bubble to $5 \%$.

e Fermentation required more than 14 days.

$f$ Method of Kauffmann and Petersen. 
TABLE 3. Summary of the biochemical reactions at 22 to $25^{\circ} \mathrm{C}$ of 33 strains of Yersinia ruckeri sp. nov. including the type strain ${ }^{a}$

\begin{tabular}{|c|c|c|c|c|}
\hline Test or substrate & Reaction & $\%+$ & $\begin{array}{l}\text { Type } \\
\text { strain }^{b}\end{array}$ & $\begin{array}{l}\text { Strains that gave } \\
\text { the less common } \\
\text { result }\end{array}$ \\
\hline$\ldots \ldots \ldots \ldots \ldots$ & - & 0 & - & \\
\hline Urease $\ldots \ldots \ldots \ldots \ldots \ldots$ & - & 0 & - & \\
\hline Indole & - & 0 & - & \\
\hline Methyl red $\ldots \ldots \ldots \ldots \ldots$ & + & 97 & + & $1561-68$ \\
\hline Voges-Proskauer $\ldots \ldots \ldots \ldots \ldots \ldots$ & - or $(+*)$ & $3(27)^{d}$ & - & $1563-68$ \\
\hline Citrate (Simmons) & $(+)$ & $3(94)$ & $t_{4}$ & $5974-61$ \\
\hline$\ldots \ldots \ldots \ldots$ & d & $27(27)$ & $+t_{2}$ & \\
\hline$\ldots \ldots \ldots \ldots \ldots \ldots \ldots \ldots \ldots$ & + or - & 82 & $t_{2}$ & $\begin{array}{l}5976-61 \\
2516-63 \\
4535-69 \\
4536-69 \\
1846-73 \\
2674-73\end{array}$ \\
\hline Gelatin liquefaction & + or $(+)$ & $52(14)$ & $t_{4}$ & \\
\hline Lysine decarboxylase $\ldots \ldots \ldots \ldots \ldots \ldots$ & + or $(+)$ & $88(12)$ & + & \\
\hline Arginine dihydrolase $\ldots \ldots \ldots$ & - & 3 & - & $1564-68$ \\
\hline Ornithine decarboxylase & + & 100 & + & \\
\hline Phenylalanine deaminase $\ldots \ldots \ldots \ldots$ & - & 0 & + & \\
\hline \multicolumn{5}{|l|}{ Glucose } \\
\hline Acid & + & 100 & + & \\
\hline$\ldots \ldots \ldots \ldots \ldots \ldots \ldots \ldots \ldots$ & -e & 9 & $-e$ & $\begin{array}{l}1564-68 \\
1848-73 \\
1852-73\end{array}$ \\
\hline Lactose & - or $(+)$ & $0(12)$ & - & \\
\hline$\ldots \ldots \ldots \ldots \ldots \ldots$ & - & 0 & - & \\
\hline Mannitol $\ldots \ldots \ldots \ldots \ldots \ldots \ldots \ldots$ & + & 100 & + & \\
\hline Dulcitol $\ldots \ldots \ldots \ldots \ldots \ldots \ldots \ldots \ldots \ldots \ldots \ldots \ldots \ldots$ & - & 0 & - & \\
\hline$\ldots \ldots \ldots \ldots \ldots$ & - & $\mathbf{0}$ & - & \\
\hline Adonitol $\ldots \ldots \ldots \ldots \ldots$ & - & 0 & - & \\
\hline$\ldots \ldots \ldots \ldots \ldots \ldots$ & - & 0 & - & \\
\hline$\ldots \ldots \ldots \ldots \ldots$ & - & 0 & - & \\
\hline Nitrate to nitrite & + or $(+)$ & $85(12)$ & + & $1560-68$ \\
\hline Oxidation-fermentation & $\mathbf{F}$ & 100 & $\mathbf{F}$ & \\
\hline Oxidase & - & 0 & - & \\
\hline$\ldots \ldots \ldots \ldots$ & - & 0 & - & \\
\hline Cetrimide & - or $(+)$ & $0(24)$ & - & \\
\hline$\ldots \ldots \ldots \ldots \ldots \ldots$ & - & 0 & - & \\
\hline \multicolumn{5}{|l|}{ Organic acids } \\
\hline Citrate & $(+)$ & $0(100)$ & +14 & \\
\hline$\ldots \ldots$ & - & 0 & - & \\
\hline
\end{tabular}

a Symbols:,$+ 90 \%$ or more strains positive within 1 or 2 days; $(+)$, positive reaction after 3 or more days (decarboxylase tests: 3 or 4 days); -, negative reaction (90\% or more); + or - , most cultures positive, some strains negative; - or + , most strains negative, some cultures positive; + or $(+)$, most reactions occur within 1 or 2 days, some are delayed; $d$, different reactions $[+,(+)$, or -$]$. F, Fermentative; $w$, weakly positive reaction.

${ }^{b}$ Ross number H1 (= 2396-61 = ATCC 29473). Subscript numerals indicate day on which reaction occurred.

c Triple sugar-iron or peptone-iron agar.

${ }^{d}$ Figures in parentheses indicate percentages of delayed reactions ( 3 days or more).

e Tiny bubble to $5 \%$.

${ }^{i}$ Method of Kauffmann and Petersen. 
biochemical reactions of $\mathrm{RM}$ bacteria resembled those of some cultures of $S$. marcescens (particularly the kiliensis biotype), S. liquefaciens, and Arizona hinshawii. At that time the genus Yersinia was not included in the family Enterobacteriaceae.

Representative strains of the RM bacterium were sent to Rudolph Hugh, Department of Microbiology, George Washington University, Washington, D.C., who made flagella stains (Leifson method) and reported that the bacteria were peritrichous (17). This observation was confirmed by electron photomicrography (see Fig. 1 in reference 17). All strains of RM bacteria were composed of gram-negative, rod-shaped cells. All were fermentative and all yielded negative oxidase tests. Erwin Neter of Children's Hospital, Buffalo, N.Y., reported (personal communication, 1974) that 12 strains of RM bacteria examined possessed the antigen common to the Enterobacteriaceae (15).

Comparison of the biochemical reactions of RM bacteria with those given by members of other genera of Enterobacteriaceae (11) indicates that the RM bacteria are more closely related to Serratia $(13,14)$ and Yersinia $(1,10)$ than to any other members of the family. However, close examination shows that there are many more biochemical differences between RM bacteria and members of the three species of Serratia than there are between the RM bacteria and members of the three species of Yersinia (Table 6). Examination of the aggregate biochemical reactions given by RM bacteria (Tables 2 and 3) and data reported for Yersinia pestis, Y. pseudotuberculosis, and Y. enterocolitica $(1,10)$ reveals many similarities, which are apparent in Table 6. Although the RM bac-

TABLE 4. DNA relatedness of RM bacteria and members of the family Enterobacteriaceae to RM strain 4535-69

\begin{tabular}{|c|c|c|c|c|c|}
\hline Source of unlabeled DNA & $\begin{array}{l}\mathrm{RBR}^{a} \\
\left(60^{\circ} \mathrm{C}\right)\end{array}$ & $\% \mathrm{D}^{b}$ & Source of unlabeled DNA & $\begin{array}{l}\mathrm{RBR}^{a} \\
\left(60^{\circ} \mathrm{C}\right)\end{array}$ & $\% \mathrm{D}^{b}$ \\
\hline RM 4535-69 & 100 & 0,0 & “Citrobacter-like" 4554-71 & 27 & \\
\hline RM 5972-61 & 95 & 0.2 & "Citrobacter-like" 4557-71 & 24 & \\
\hline RM 2396-61 & 94 & 0.1 & Hafnia alvei $\ldots \ldots \ldots$ & 24 & 15.7 \\
\hline RM 2514-63 & 94 & 0.1 & Erwinia nigrifluens EN101 & 21 & \\
\hline Serratia marcescens 868-56 & 31 & 13.0 & Pectobacterium carotovorum & & \\
\hline S. marcescens SM6 W2 & 31 & 14.8 & EC495 & 21 & 18.3 \\
\hline S. marcescens $866-67$ & 29 & 15.2 & Citrobacter freundii $\mathbf{8 7 6 - 5 8}$ & 21 & \\
\hline S. marcescens $1201-65$ & 28 & & Enterobacter cloacae 1347-71 & 20 & 16.0 \\
\hline S. marcescens (biotype kiliensis) & 26 & & Pectobacterium carnegieana & & \\
\hline S. marcescens $863-57$ & 25 & 15.0 & EC186 & 19 & \\
\hline S. marcescens $864-57$ & 25 & 14.7 & Enterobacter agglomerans $\mathbf{E H} 103$ & 19 & 16.4 \\
\hline Serratia liquefaciens $1107-57 \ldots$ & 29 & & Citrobacter freundii $\mathbf{4 6 0 - 6 1} \ldots \ldots$ & 19 & 14.6 \\
\hline S. liquefaciens 1284-57 . . . . & 28 & 14.4 & Salmonella typhimurium LT2 & 19 & 13.3 \\
\hline S. liquefaciens $1286-57$ & 27 & & Escherichia coli K-12 ....... & 18 & 16.1 \\
\hline S. liquefaciens $446-68$. & 27 & & Enterobacter aerogenes 1627-66 & 18 & 14.6 \\
\hline S. liquefaciens (biotype & & & Klebsiella rhinoscleromatis $895-68$ & 18 & 12.8 \\
\hline lipolyticus) & 26 & 14.8 & Erwinia amylovora EA178 & 18 & 16.7 \\
\hline Serratia rubidaea $5474-68$ & 24 & & Pectobacterium cypripedii & 17 & \\
\hline S. rubidaea 4445-64 .... & 23 & 14.1 & Enterobacter cloacae (yellow) 256- & & \\
\hline S. rubidaea 4057-71 & 21 & & $4 \ldots \ldots \ldots \ldots \ldots$ & 17 & \\
\hline S. rubidaea $934-72$. & 21 & 14.2 & Proteus morganii & 15 & \\
\hline "Citrobacter-like" 4553-71 & 29 & & Proteus mirabilis PM1 & 9 & \\
\hline "Citrobacter-like" 4556-71 & 28 & 15.8 & Edwardsiella tarda $3592-64$ & 9 & \\
\hline "Citrobacter-like" 4552-71 & 27 & & & & \\
\hline
\end{tabular}

${ }^{a}$ RBR, Relative binding ratio. Relative binding ratio is a convenient way to express percent DNA relatedness.

$$
\mathrm{RBR}=\frac{\% \text { heterologous DNA reaction }}{\% \text { homologous DNA reaction }} \times 100
$$

\footnotetext{
${ }^{b} \% \mathrm{D}$, Percent divergence, calculated on the assumption that a 1-C degree decrease in thermal stability of a DNA duplex is caused by each $1 \%$ of unpaired bases within that duplex (3). For example, consider organisms $\mathrm{A}$ and $\mathrm{B}$ that are 50\% related. An A-A duplex has a mean thermal stability of $90^{\circ} \mathrm{C}$, and an A-B duplex has a mean thermal stability of $80^{\circ} \mathrm{C}$. The $\mathrm{D}$ in related DNA is $10 \%$. Reactions were done two to four times. DNA reassociation in the homologous RM reaction averaged $83 \%$. DNA reassociation in the homologous RM reaction averaged $83 \%$. DNA reassociation in control reactions that contained labeled DNA in the absence of unlabeled DNA were $2 \%$ or less.
} 
TABLE 5. DNA relatedness of serratiae and yersiniae to RM bacteria

\begin{tabular}{|c|c|c|c|}
\hline \multirow[b]{2}{*}{ Source of labeled DNA } & \multicolumn{3}{|c|}{ Relatedness to RM bacteria } \\
\hline & $\begin{array}{l}\mathrm{RBR}^{a} \\
\left(60^{\circ} \mathrm{C}\right)\end{array}$ & $\begin{array}{c}\% D^{b} \\
\left(60^{\circ} \mathrm{C}\right)\end{array}$ & $\begin{array}{l}\mathbf{R B R}^{\alpha} \\
\left(75^{\circ} \mathrm{C}\right)\end{array}$ \\
\hline $\begin{array}{rr}\text { Serratia marcescens } \\
868-57\end{array}$ & $26(4)^{c}$ & 17.0 & $7(2)$ \\
\hline S. liquefaciens $446-68$ & $30(2)$ & 17.2 & $10(2)$ \\
\hline S. rubidaea $934-72$ & $24(4)$ & 16.6 & \\
\hline $\begin{array}{l}\text { Yersinia enterocolitica } \\
501-70\end{array}$ & $30(4)$ & 15.1 & $8(1)$ \\
\hline $\begin{array}{l}\text { Y. pseudotuberculosis } \\
\text { P105 }\end{array}$ & $30(3)$ & 15.1 & $8(2)$ \\
\hline
\end{tabular}

$a$ " See footnotes to Table 4.

c The numbers in parentheses indicate the number of strains tested. All reactions were done at least twice. Average DNA reassociation in homologous reactions was: $S$. marcescens, $78 \%$ at $60^{\circ} \mathrm{C}$ and $86 \%$ at $75^{\circ} \mathrm{C} ; S$. liquefaciens, $74 \%$ at $60^{\circ} \mathrm{C}$ and $75 \%$ at $75^{\circ} \mathrm{C} ; S$. rubidaea, $75 \%$ at $60^{\circ} \mathrm{C} ; Y$. enterocolitica, $78 \%$ at $60^{\circ} \mathrm{C}$ and $74 \%$ at $75^{\circ} \mathrm{C} ; Y$. pseudotuberculosis, $69 \%$ at $60^{\circ} \mathrm{C}$ and $65 \%$ at $75^{\circ} \mathrm{C}$. DNA reassociations in control reactions that contained labeled DNA in the absence of unlabeled DNA were $3 \%$ or less.

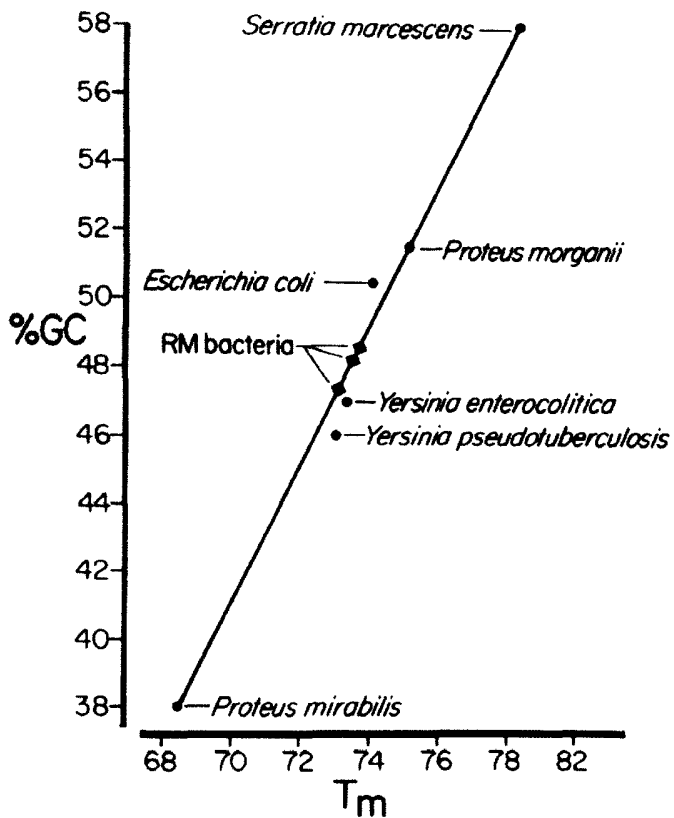

FiG. 1. Spectrophotometric determination of $G+C$ composition in RM bacteria. The increase in ultraviolet absorption at $260 \mathrm{~nm}$ with increased temperature was measured for four strains of RM bacteria and several strains of Enterobacteriaceae of known $G+C$ composition. $T_{m}$ is temperature at which onehalf of the maximal increase in ultraviolet absorption (hyperchromicity) has occurred. The $T_{m}$ values for $R M$ bacteria ( $\bullet$ ) were $73.7,73.5$, and $73.2^{\circ} \mathrm{C}$ (two strains). teria biochemically are most closely related to yersiniae, they are easily differentiable from all three established species of Yersinia (Table 6) and should be recognized as a new species within that genus.

DNAs from strains of a given species are usually at least $70 \%$ related $(4,6)$. The four RM strains certainly belong to the same species on the basis of DNA relatedness. Except for most protei, species of Enterobacteriaceae share a "core" DNA relatedness of 15 to $20 \%$. RM bacteria exhibit this level of core relatedness. They are not closely related to any species of Enterobacteriaceae but show about $30 \%$ relatedness to species of Serratia and Yersinia. Thus, from DNA data, one can argue that RM bacteria can be put in either of these genera.

The G+C ratios in Enterobacteriaceae are from $37 \%$ in some protei to almost $60 \%$ in strains of Serratia and Klebsiella. Definitive classification based on $\mathrm{G}+\mathrm{C}$ rarely is possible. Similar $\mathrm{G}+\mathrm{C}$ ratios cannot be equated with species similarity (humans, Bacillus subtilis, and Proteus rettgeri have similar $\mathrm{G}+\mathrm{C}$ ratios), but organisms with markedly different $\mathrm{G}+\mathrm{C}$ ratios cannot belong to the same species. The $\mathrm{G}+\mathrm{C}$ ratios of serratiae $(58 \%)$ and yersiniae (46 to $48 \%$ ) are significantly different. The $\mathrm{G}+\mathrm{C}$ ratios in four RM bacteria were approximated to be between 47.5 and $48.5 \%$. These results indicate that RM bacteria do not belong to the genus Serratia and are consistent with those for the genus Yersinia.

The name Yersinia ruckeri is proposed for the RM bacterium (ruck'er.i. M. L. gen. n. ruckeri of Rucker, named in honor of Robert $R$. Rucker, who spent many years studying redmouth disease and its etiological agents). Strain 2396-61 (= American Type Culture Collection [ATCC] 29473) is the type strain of the species.

According to the proposals made, the nomenclature of the members of the tribe Yersinieae is as follows:

Tribe Yersinieae Martinevskij

Genus Yersinia van Loghem

1. Yersinia pestis (Lehmann and Neumann) van Loghem

2. Yersinia pseudotuberculosis (Pfeiffer) van Loghem

3. Yersinia enterocolitica (Schleifstein and Coleman) Frederiksen (species will be subdivided in the future [8]).

4. Yersinia ruckeri sp. nov.

\section{REPRINT REQUESTS}

Address reprint requests to: Don J. Brenner, Building 1 Room B311, Center for Disease Control, Atlanta, GA 30333 . 
TABLE 6. Major biochemical differences between Y. ruckeri, serratiae, and other yersiniae

\begin{tabular}{|c|c|c|c|c|c|c|c|}
\hline Test or substrate & $\begin{array}{l}\text { Y. ruckeri } \\
\left(22-25^{\circ} \mathrm{C}\right)^{a}\end{array}$ & $\begin{array}{c}\text { S. marces- } \\
\text { cens } \\
\left(35-37^{\circ} \mathrm{C}\right)\end{array}$ & $\begin{array}{l}\text { S. lique- } \\
\text { faciens } \\
\left(35-37^{\circ} \mathrm{C}\right)\end{array}$ & $\begin{array}{c}\text { S. rubi- } \\
\text { daea } \\
\left(35-37^{\circ} \mathrm{C}\right)\end{array}$ & $\begin{array}{l}\text { Y. pestis } \\
\left(35-37^{\circ} \mathrm{C}\right)\end{array}$ & $\begin{array}{l}\text { Y. pseudo- } \\
\text { tuberculo- } \\
\text { sis } \\
\left(22-25^{\circ} \mathrm{C}\right)\end{array}$ & $\begin{array}{c}\text { Y. entero- } \\
\text { colitica } \\
\left(22-25^{\circ} \mathrm{C}\right)\end{array}$ \\
\hline Urease & $0^{b}$ & $40^{w}(22)^{c}$ & & & & 100 & $91(7)$ \\
\hline Indole & 0 & & & & & & \\
\hline Methyl red & 97 & 18 & 37 & 24 & & & \\
\hline Voges-Proskauer & $3(21)$ & 99 & 86 & 94 & & & 87 \\
\hline Citrate (Simmons) & $3(94)$ & $98(1)$ & $94(6)$ & $88(2)$ & & & \\
\hline $\mathrm{KCN}$ & 24 & 99 & 92 & & & & \\
\hline Motility $\left(35^{\circ} \mathrm{C}\right)$ & 85 & 95 & 93 & 88 & & 0 & 0 \\
\hline $\begin{array}{l}\text { Gelatin liquefaction } \\
\qquad\left(22^{\circ} \mathrm{C}\right)\end{array}$ & $52(42)$ & & & & 0 & $\mathbf{0}$ & $\mathbf{0}$ \\
\hline $\begin{array}{l}\text { Lysine decarboxyl- } \\
\text { ase }\end{array}$ & $88(12)$ & & & & 0 & 0 & $\mathbf{0}$ \\
\hline $\begin{array}{l}\text { Ornithine decarbox- } \\
\text { ylase }\end{array}$ & 100 & & 0 & 0 & 0 & 0 & \\
\hline Malonate & 0 & & & 86 & & & \\
\hline Sodium acetate & $0(24)$ & 84 & $38(38)$ & $67(14)$ & $\mathrm{ND}^{e}$ & 0 & $7(44)$ \\
\hline Gas from glucose & 12 & 53 & $73(1)$ & $35(4)$ & & & \\
\hline Lactose & $0(12)$ & & $16(21)$ & 100 & & & \\
\hline Sucrose & 0 & 99 & 98 & 96 & & & 96 \\
\hline Salicin & 0 & $95(2)$ & 96 & $88(4)$ & 19 & $5(95)$ & $13(15)$ \\
\hline Adonitol & 0 & $47(14)$ & & $88(2)$ & & & \\
\hline Inositol & 0 & $77(6)$ & $64(26)$ & $35(16)$ & & & $9(32)$ \\
\hline Sorbitol & $\mathbf{0}$ & 99 & 97 & & & & $9 y$ \\
\hline Arabinose & 0 & & 97 & 100 & 30 & $50(45)$ & $99(1)$ \\
\hline Raffinose & 0 & & $91(5)$ & 96 & & 20 & \\
\hline Rhamnose & 0 & & & & & 100 & \\
\hline Xylose & 0 & $7(17)$ & $99(1)$ & 98 & 100 & 100 & $36(3)$ \\
\hline Cellobiose & 0 & $14(25)$ & $27(36)$ & 90 & & & $88(12)$ \\
\hline Erythritol & 0 & $8(25)$ & & & & & \\
\hline Esculin & 0 & 73 & 95 & 90 & 100 & 100 & $15(21)$ \\
\hline Melibiose & 0 & & $74(8)$ & 96 & & $90(10)$ & \\
\hline Amygdalin & 0 & 100 & 100 & 94 & & & $95(4)$ \\
\hline Deoxyribonuclease & 0 & 97 & 88 & 100 & $(100)$ & $0(30)$ & \\
\hline Pigment & 0 & 16 & & 61 & & & \\
\hline \multicolumn{8}{|l|}{ Organic acids $f$} \\
\hline Citrate & $0(100)$ & 100 & 65 & $2(68)$ & ND & & $0(25)$ \\
\hline D-Tartrate & 0 & $2(19)$ & 22 & & & & \\
\hline
\end{tabular}

a The results given for $Y$. ruckeri (from Table 2), Y. pseudotuberculosis, and Y. enterocolitica (references 1 and 10) were obtained at 22 to $25^{\circ} \mathrm{C}$, whereas those given for the species of Serratia $(11,13,14)$ and for $Y$. pestis $(1,10)$, were for cultures incubated at 35 to $37^{\circ} \mathrm{C}$. S. liquefaciens is known to be more reactive at 22 to $25^{\circ} \mathrm{C}$ than at 35 to $37^{\circ} \mathrm{C}(11,13,14)$, but reactions given by $S$. marcescens, $S$. rubidaea, and $Y$. pestis are not known to be affected significantly by incubation at temperatures between 22 and $37^{\circ} \mathrm{C}$. Therefore, it is believed that the data given for the various bacteria listed in Table 5 can be compared.

${ }^{b}$ Percent positive within 1 or 2 days.

${ }^{c}$ Percent positive in 3 or more days.

$d$ The majority ( 67 to $83 \%$ ) of cultures isolated in the United States have been indole positive $(2,7,10)$.

e ND, Not determined.

${ }^{f}$ Method of Kauffmann and Petersen.

\section{LTERATURE CITED}

1. Bejot, J., J. M. Alonso, and H. H. Mollaret. 1975. La diagnostic bactériologique des yersinioses humaines (infections à Yersinia pseudotuberculosis et Yersinia enterocolitica). Med. Maladies Infect. 54:233-236.

2. Bissett, M. L. 1976. Yersinia enterocolitica isolates from humans in California, 1968-1975. J. Clin. Microbiol. 4:137-144.

3. Bonner, T. I., D. J. Brenner, B. R. Neufeld, and R. J. Britten. 1973. Reduction in the rate of DNA reas- sociation by sequence divergence. J. Mol. Biol. 81: 123-135.

4. Brenner, D. J., and S. Falkow. 1971. Molecular relationships among members of the Enterobacteriaceae. Adv. Genet. 16:81-118.

5. Brenner, D. J., G. R. Fanning, A. Rake, and K. E. Johnson. 1969. A batch procedure for thermal elution of DNA from hydroxyapatite. Anal. Biochem. 28:447-459.

6. Brenner, D. J., G. R. Fanning, F. J. Skerman, and S. Falkow. 1972. Polynucleotide sequence divergence 
among strains of Escherichia coli and clasely related organisms. J. Bacteriol. 109:953-965.

7. Brenner, D. J., A. G. Steigerwalt, D. P. Falcao, R. E. Weaver, and G. R. Fanning. 1976. Characterization of Yersinia enterocolitica and Yersinia pseudotuberculosis by deoxyribonucleic acid hybridization and by biochemical reactions. Int. J. Syst. Bacteriol. 26:180-194.

8. Brenner, D. J., A. J. Steigerwalt, G. V. Miklus, and G. R. Fanning. 1973. Deoxyribonucleic acid relatedness among erwiniae and other Enterobacteriaceae: the soft-rot organisms (genus Pectobacterium Waldee). Int. J. Syst. Bacteriol. 23:205-216.

9. Britten, R. J., and D. E. Kohne. 1966. Nucleotide sequence repetition in DNA. 1966. Carnegie Inst. Washington Yearb. 65:78-106.

10. Darland, G., W. H. Ewing, and B. R. Davis. 1974. The biochemical characteristics of Yersinia enterocolitica and Yersinia pseudotuberculosis. Center for Disease Control, Atlanta, Ga.

11. Edwards, P. R., and W. H. Ewing. 1972. Identification of Enterobacteriaceae, 3rd. ed. Burgess Publishing Co. Minneapolis, Minn.

12. Ewing, W. H., and B. R. Davis. 1970. Media and tests for differentiation of Enterobacteriaceae. Center for Disease Control, Atlanta, Ga.

13. Ewing, W. H., and B. R. Davis. 1972. Biochemical characterization of Serratia marcescens. Public Health
Lab. 30:211-226.

14. Ewing, W. H., B. R. Davis, M. A. Fife, and E. F. Leseel. 1973. Biochemical characterization of Serratia liquefaciens (Grimes and Hennerty) Bascomb et al. (formerly Enterobacter liquefaciens) and Serratia rubidaea (Stapp) comb. nov. and designation of neotype strains. Int. J. Syst. Bacteriol. 23:217-225.

15. Mäkelä, P. H., and H. Mayer. 1976. Enterobacterial common antigen. Bacteriol. Rev. 40:519-632.

16. Mollaret, H. H., and E. Thal. 1974. Genus XI. Yersinia van Loghem 1944, 15, p. 330-332. In R. E. Buchanan and N. E. Gibbons (ed.), Bergey's manual of determinative bacteriology, 8 th ed. The Williams \& Wilkins Co., Baltimore.

17. Ross, A. J., R. R. Rucker, and W. H. Ewing. 1966 Description of a bacterium associated with redmouth disease of rainbow trout (Salmo gairdneri). Can. J. Microbiol. 12:763-770.

18. Rucker, R. R. 1966. Redmouth disease in rainbow trout (Salmo gairdneri). Bull. Off. Int. Epiz. 65:825-830.

19. Steigerwalt, A. G., G. R. Fanning, M. A. Fife-Asbury, and D. J. Brenner. 1976. DNA relatedness among species of Enterobacter and Serratia. Can. J. Microbiol. 22:121-137.

20. Wobeser, G. 1973. An outbreak of redmouth disease in rainbow trout (Salmo gairdneri) in Saskatchewan. J. Fish. Res. Board Can. 30:571-575. 